\title{
National aspects of food security of Russia
}

\author{
Elena Karanina ${ }^{1, *}$, Ekaterina Sapozhnikova ${ }^{1}$, Dmitry Loginov ${ }^{1}$, Anatoly Holkin ${ }^{2}$, Elena \\ Sergievskaya ${ }^{2}$, and Andrew Zurakhovskii ${ }^{2}$ \\ ${ }^{1}$ Vyatka State University, Moskovskaya str., 36, Kirov, 610000, Russia \\ ${ }^{2}$ Moscow State University of Civil Engineering, Yaroslavskoe shosse, 26, Moscow, 129337, Russia
}

\begin{abstract}
Instability of a foreign policy situation and deepening of financial crisis actualize need of monitoring of food security's condition as objective condition of economic sovereignty of Russia. Modern approaches to definition of food security of the state are considered in article. Critical evaluation of separate provisions of the Doctrine of food security of the Russian Federation is given. The analysis of a condition of food security of Russia in the directions of independence, economic and physical availability of the food is carried out on the basis of statistical data. Food security in Russia was reflected in the political decisions that defined the new economic policy of the state in the foreign market. modern import substitution program has shown its effectiveness, which is based on the absence of alternative paths of development. An important condition is the slow pace of development of the internal economy of Russia in conditions when domestic markets competition is virtually nonexistent. Food is a priority in the development of society, ensuring political and social balance, therefore, organizational solutions discussed in this material has a transdisciplinary character. The author's conclusions can be useful to researchers who are trying to decide how macroeconomic objectives, and conducting research for innovative solutions in many sectors of the economy.
\end{abstract}

\section{Introduction}

The intensification of strengthening of Russia's national sovereignty actualize problems of ensuring food security of the state. The considerable part of problems is reduced to lack of the unified conceptual framework of food security both within public administration and in the field of carrying out applied scientific researches. Since 1996 attempts of adoption of the federal law "About food security" were made, however the offered projects have been rejected because of lack of the Government's financial conclusion. In 2010 the Decree of the Russian President has approved the Doctrine of food security within which at the legislative level definition and indicators of Russia's food security are fixed. In spite of the fact that the Doctrine regulates 14 indicators of an assessment of a condition of food security in a section of spheres of consumption, production and national competitiveness, the organization of management, only one indicator includes criteria values: specific weight

\footnotetext{
${ }^{*}$ Corresponding author: angela-1309.m@yandex.ru
} 
of domestic agricultural production in a total amount of commodity resources [1]. It has led to the fact that the majority of measures of the state support both on federal, and at the regional level is reduced to the solution of questions of food self-sufficiency while the food security integrates economic and social aspects of life of the population and demands inclusion of wider range of indicators.

\section{Methods}

Researches of The Economist Intelligence Unit company with assistance of the American multinational company Dupon include the fullest complex of indicators of a food security's condition. The Global Food Security Index considers the core issues of affordability, availability, and quality across a set of 109 countries. The index is a dynamic quantitative and qualitative benchmarking model, constructed from 28 unique indicators, that measures these drivers of food security across both developing and developed countries. In 20132014 Russia was on the 40th place, and in 2015 has taken the 43rd place, significantly yielding a position to the USA and EU countries that testifies to serious problems in this sector of national security (Table 1).

The important direction of the conducted research is definition of strong and weak positions in system of ensuring food security by assignment of a mark assessment concerning separate indicators. As of 2015 in Russia values of the majority of indicators were in range from 25.0 to 75.0 points that corresponded to parameters of moderate positions (Table 2). Weak positions have been defined concerning three indicators which can be carried to political factors of ensuring state's food security. It should be noted that these indicators aren't included into the Russian system of monitoring of food security that speaks about need of her improvement taking into account the international approach [2-7].

Table 1. An index of global food security of the countries of the world in 2015 according to The Economist Intelligence Unit.

\begin{tabular}{|l|c|c|c|c|c|c|c|c|}
\hline \multirow{2}{*}{ Country } & \multicolumn{2}{|c|}{ Overall score } & \multicolumn{2}{c|}{ Affordability } & \multicolumn{2}{c|}{ Availability } & \multicolumn{2}{c|}{$\begin{array}{c}\text { Quality and } \\
\text { safety }\end{array}$} \\
\cline { 2 - 10 } & Rating & Scores & Rating & Scores & Rating & Scores & Rating & Scores \\
\hline United States & 1 & 89.0 & 2 & 92.1 & 1 & 87.0 & 3 & 86.4 \\
\hline France & 10 & 83.8 & 19 & 84.2 & 9 & 81.7 & 2 & 88.5 \\
\hline Spain & 20 & 78.9 & 22 & 82.1 & 18 & 73.4 & 5 & 86.0 \\
\hline Saudi Arabia & 30 & 72.8 & 25 & 80.6 & 33 & 67.7 & 43 & 67.3 \\
\hline Panama & 40 & 65.4 & 41 & 65.9 & 37 & 66.2 & 49 & 62.0 \\
\hline Russia & $\mathbf{4 3}$ & $\mathbf{6 3 . 8}$ & $\mathbf{3 3}$ & $\mathbf{7 1 . 7}$ & $\mathbf{3 9}$ & $\mathbf{5 2 . 6}$ & $\mathbf{2 8}$ & $\mathbf{7 4 . 9}$ \\
\hline Bulgaria & 50 & 61.0 & 38 & 68.7 & 62 & 54.9 & 56 & 58.6 \\
\hline Ecuador & 60 & 56.0 & 59 & 55.6 & 62 & 54.9 & 52 & 59.7 \\
\hline Guatemala & 70 & 49.7 & 70 & 47.5 & 77 & 50.0 & 62 & 54.1 \\
\hline Benin & 80 & 41.7 & 80 & 36.4 & 7 & 48.8 & 94 & 35.7 \\
\hline Yemen & 90 & 37.3 & 76 & 37.7 & 102 & 38.7 & 99 & 32.4 \\
\hline Niger & 100 & 33.6 & 97 & 24.9 & 100 & 39.4 & 89 & 39.7 \\
\hline Burundi & 109 & 25.1 & 107 & 19.4 & 109 & 25.6 & 91 & 38.1 \\
\hline
\end{tabular}

Table 2. Indicators of food security of Russia in 2015 according to The Economist Intelligence Unit.

\begin{tabular}{|c|c|}
\hline \multicolumn{1}{|c|}{ Indicator } & Scores \\
\hline Strengths (Scores 75 or more) & \\
\hline Presence of food safety net programmes & 100.0 \\
\hline Nutritional standards & 100.0 \\
\hline
\end{tabular}




\begin{tabular}{|c|c|}
\hline Proportion of population under global poverty line & 99.7 \\
\hline Food loss & 96.5 \\
\hline Food safety & 95.3 \\
\hline Agricultural import tariffs & 83.2 \\
\hline Access to financing for farmers & 75.0 \\
\hline Moderate (Scores 25 to 75) & 72.1 \\
\hline Sufficiency of supply & 71.7 \\
\hline Protein quality & 69.6 \\
\hline Diet diversification & 68.6 \\
\hline Volatility of agricultural production & 63.1 \\
\hline Micronutrient availability & 55.2 \\
\hline Agricultural infrastructure & 50,9 \\
\hline Urban absorption capacity & 47.2 \\
\hline Wood consumption as a share of household expenditure & 30.0 \\
\hline Weaknesses (Scores less than 25) & 22.2 \\
\hline Political stability risk & 12.5 \\
\hline Corruption & 0.0 \\
\hline Public expenditure on agricultural R\&D & \\
\hline Toss domestic product per capita (PPP)
\end{tabular}

National approach to an assessment of food security is focused on a problem of food independence that in the conditions of Russia's membership in the WTO and orientation to import substitution certainly is a priority. Food independence is defined by the level of satisfaction of population's needs for food due to own production of main types of agricultural production, raw materials and the food [8-15].

The technique of measurement of food independence's level and also threshold values of this indicator in a section of eight groups of food is given in the Doctrine of food security of the Russian Federation. However, the called provisions of the Doctrine demand critical evaluation.

First, as criterion the specific weight of domestic agricultural production in a total amount of commodity resources (with the passing stocks) domestic market is defined. If to follow the offered technique, then such indicators as volume of the exported production, a ratio of volumes of import and export which undoubtedly characterize food independence of the state completely drop out of calculations.

Secondly, orientation to full satisfaction of requirements of the population with production of own production doesn't consider the economic laws defining division of labor in the world market, the solution of global problems of fight against hunger and poverty. The countries of the EU use import goods of $15-20 \%$ of the requirement, and in the USA more than $17 \%$ of foodstuff are brought in. Threshold values of population's security with the food due to own production is defined in the Doctrine. For the most part of products from the offered list the specified indicator exceeds a mark of $80 \%$ which is given in recommendations of FAO. In our opinion this technique has to be used for definition of groups of foodstuff demanding additional measures of the state support directed to expansion of their production, but to estimate in a presented way the level of food security isn't correct.

Thirdly, consumption by the population of food not always meets rational standards while the level of food independence is estimated on the level of the actual consumption. Besides, according to the Doctrine rational norms of consumption have to answer the modern scientific principles of optimum food, however concrete values of these indicators aren't given. The norms developed by institute of food of the Russian academy of medical sciences, World Health Organization of the UN and the Ministry of Health of the Russian Federation considerably differ (Table 3 ). Taking into account the called value fact rational norms of consumption of food are demanded by specifications. 
Table 3. Rational norms of food's consumption, $\mathrm{kg}$ a year on the person [9].

\begin{tabular}{|l|c|c|c|}
\hline \multicolumn{1}{|c|}{ Food product } & $\begin{array}{c}\text { Institute of Nutrition of } \\
\text { the Russian Academy of } \\
\text { Medical Sciences }\end{array}$ & $\begin{array}{c}\text { World Health } \\
\text { Organization }\end{array}$ & $\begin{array}{c}\text { Ministry of } \\
\text { Health } \\
\text { (Russia) }\end{array}$ \\
\hline Grain products & 107 & 120.5 & $95-105$ \\
\hline Potatoes & 117 & 96.7 & $95-100$ \\
\hline Vegetables and melon & 145 & 140.3 & $120-140$ \\
\hline Meat and meat products & 86 & 70.1 & $70-75$ \\
\hline Egg (pieces) & 298 & 243 & 260 \\
\hline Fish and fish products & 23.7 & 8.3 & $18-22$ \\
\hline Sugar and confectionery & 40.7 & 36.5 & $24-28$ \\
\hline Oil vegetable and other fats & 13.6 & 13.1 & $10-12$ \\
\hline Milk and dairy products & 404 & 360 & $320-340$ \\
\hline
\end{tabular}

Level of Russia's food independence is determined with use of the technique fixed by the Doctrine. Results of calculations are presented in table 4. Food independence has been completely reached on grain, potatoes and fish production during the analyzed period. The indicator of food independence on meat and meat products was below threshold value $(85 \%)$, however the tendency of his increase is observed. It is explained by implementation of the priority national project "Development of Agrarian and Industrial Complex", further the State program of development of agriculture and regulation of the markets of agricultural production, raw materials and the food.

Level of food independence on milk and dairy products has been reached in 2000 , during the subsequent period it was considerably reduced. In 2014 this indicator has made $78.3 \%$ that is 11.7 items lower than threshold value (Table 4).

Table 4. Indicators of Russia's food independence of on the main products in 2000-2014, (\%).

\begin{tabular}{|l|c|c|c|c|c|}
\hline \multicolumn{1}{|c|}{ Food product } & Standard & 2000 & 2005 & 2010 & 2014 \\
\hline Grain & $>95$ & 95.9 & 117.5 & 122.4 & 144.7 \\
\hline Potatoes & $>95$ & 101.2 & 102.0 & 101.0 & 103.7 \\
\hline Meat and meat products & $>85$ & 69.1 & 62.0 & 72.4 & 83.5 \\
\hline Milk and dairy products & $>90$ & 91.3 & 82.3 & 80.6 & 78.3 \\
\hline Fish and fish products & $>80$ & - & - & 117.5 & 114.4 \\
\hline
\end{tabular}

Determination of dependence of the food market on external deliveries is the important direction of research. This indicator considers not only the entering, but also proceeding food streams and represents a ratio between volumes of import and internal production minus export. The analysis of the specified indicator has shown that dependence of Russia's food market on main types of production is significantly differentiated (Table 5). Such types of the food as grain, potatoes, eggs and egg products are least dependent on import. The situation is ambiguous concerning other resources. Despite the high level of dependence on external deliveries of vegetable and meat production this indicator doesn't exceed threshold value in $30 \%$. In 2014 degree of dependence on import of milk and dairy products has made $30 / 5 \%$ and continues to grow.

The analysis of export and import of dairy products has shown that in 2014 the volume of delivery of milk and cream by $9 / 6$ times exceeded export volume; butter and fats by $28 / 8$ times; cheese and cottage cheese - by $12 / 5$ times.

It is necessary to strengthen attention to branch of dairy cattle breeding for a conclusion him from a crisis situation. Implementation of the following measures is necessary:

- creation of the mechanism of agricultural enterprises' economic interest in milk increase in production;

- formation of full-fledged food supply;

- increase of efficiency of cows due to improvement of their breeding qualities. 
The specified measures have to be urgent as the condition of dairy animal husbandry has significant effect on development of country's food market in general. The end results of milk and dairy products' production depend not only on a level of development of direct agriculture, but also on infrastructure of the market, namely: existence of the enterprises for processing of dairy products, security with the service centers, existence of shots and organization of their preparation. Rational use of state regulation of formation of the food markets and infrastructure of dairy cattle breeding has essential value for the effective organization of production of milk [10,15-17].

Table 5. Indicators of food dependence on external deliveries in Russia in 2000-2014.

\begin{tabular}{|c|c|c|c|c|}
\hline Indicator & 2000 & 2005 & 2010 & 2014 \\
\hline \multicolumn{5}{|c|}{ Production, million tons } \\
\hline Grain & 65.4 & 77.8 & 61.0 & 105.3 \\
\hline Potatoes & 29.5 & 28.1 & 21.1 & 31.5 \\
\hline $\begin{array}{l}\text { Vegetables and melon } \\
\text { cultures }\end{array}$ & 11.4 & 12.1 & 13.3 & 16.9 \\
\hline Meat and meat products & 4.4 & 5.0 & 7.2 & 9.1 \\
\hline Milk and dairy products & 32.3 & 30,8 & 31.8 & 30.8 \\
\hline $\begin{array}{l}\text { Eggs and egg products } \\
\text { (million pieces) }\end{array}$ & 34085 & 37091 & 40600 & 41859 \\
\hline \multicolumn{5}{|l|}{ Export, million tons } \\
\hline Grain & 1.3 & 12,2 & 13,9 & 30,1 \\
\hline Potatoes & 0.03 & 0,03 & 0,09 & 0,07 \\
\hline $\begin{array}{l}\text { Vegetables and melon } \\
\text { cultures }\end{array}$ & 0.2 & 0.9 & 0.5 & 0.8 \\
\hline Meat and meat products & 0.04 & 0.07 & 0,1 & 0.1 \\
\hline Milk and dairy products & 0.5 & 0.5 & 0.5 & 0.6 \\
\hline $\begin{array}{l}\text { Eggs and egg products } \\
\text { (million pieces) }\end{array}$ & 326 & 197 & 244 & 305 \\
\hline \multicolumn{5}{|l|}{ Import, million tons } \\
\hline Grain & 4.7 & 1,5 & 0.4 & 0,9 \\
\hline Potatoes & 0.6 & 0.5 & 1.1 & 1,0 \\
\hline $\begin{array}{l}\text { Vegetables and melon } \\
\text { cultures }\end{array}$ & 2.2 & 3.5 & 3.2 & 2,9 \\
\hline Meat and meat products & 2.1 & 3.1 & 2.9 & 2.0 \\
\hline Milk and dairy products & 4.7 & 7.1 & 8.2 & 9.2 \\
\hline $\begin{array}{l}\text { Eggs and egg products } \\
\text { (million pieces) }\end{array}$ & 1168 & 882 & 901 & 1235 \\
\hline \multicolumn{5}{|l|}{$\begin{array}{l}\text { Dependence on external } \\
\text { deliveries, } \%\end{array}$} \\
\hline Grain & 7.3 & 2,3 & 0.8 & 1.2 \\
\hline Potatoes & 2.0 & 1.8 & 5.2 & 3.2 \\
\hline $\begin{array}{l}\text { Vegetables and melon } \\
\text { cultures }\end{array}$ & 19.6 & 31.3 & 25.0 & 18.0 \\
\hline Meat and meat products & 48.2 & 62.9 & 40.8 & 22.2 \\
\hline Milk and dairy products & 14.8 & 23.4 & 26.2 & 30.5 \\
\hline $\begin{array}{l}\text { Eggs and egg products } \\
\text { (million pieces) }\end{array}$ & 3.5 & 2.4 & 2.2 & 3.0 \\
\hline
\end{tabular}

Level of achievement of rational norms of consumption of foodstuff per capita acts as one of the main target indicators of food security. The ratio of the actual volumes of food's consumption with the rational norms established by the Ministry of Health of the Russian Federation allows to speak about physical availability of the food. Calculations have shown 
that in 2014 the actual level of consumption of 7 of 10 food products' groups exceeds rational rates (Table 6). Level of consumption of bread, potatoes, sugar and vegetable oil is traditionally high. Discrepancy of real consumption rational is noted on vegetables and melon cultures, fruit and berries, milk and dairy products. At the same time, if consumption of vegetables and fruit annually increases, then consumption of milk and dairy products rather steadily and doesn't reach norm on average for $28 \%$. It once again testifies to need of stimulation of effective production of milk for the purpose of increase of its physical availability to the population, and also achievement of indicators of food security on this indicator.

The analysis of quantitative indices of food's consumption has to be added with qualitative characteristics of a diet which include determination of nutrition and power value of the products consumed by the population. The ratio of the actual indicators with norms of physiological needs for energy and the foodstuff established by Russian consumer supervision has shown that the power value of food doesn't meet the recommended standards despite increase in consumption of proteins and fats in 2000-2014 (Table 7) [11]. In 2014 the power value of a diet has made $91.3 \%$ of the recommended standard of average daily consumption in $2850 \mathrm{kcal}$. Russia also considerably concedes to the developed countries where average daily consumption of kilocalories per capita varies from 3300 (Italy) to 3500 (Great Britain, Germany, France) and reaches 3700 in the USA $[12,16,18]$. Content of fats is exceeded for $10.5 \%$ in a daily diet due to excess consumption of sausages, eggs, mayonnaise and meat semi-finished products. The insufficient use of carbohydrates to $20 \%$ is at the same time observed.

The qualitative characteristic of a food allowance is in close interrelation with economic availability of the food as the possibility of acquisition of products directly depends on the level of the income of the population. According to the Doctrine of food security of the Russian Federation economic availability is understood as a possibility of acquisition of foodstuff at the developed prices in volumes and the range which there aren't less established rational norms of consumption. In this regard it is expedient to conduct research of economic availability of the food taking into account differentiation of the income of the population. The analysis of a daily diet on decile groups depending on the average per capita located income shows that seven lower groups suffer from malnutrition: in their diets the lack of proteins is felt, and the caloric content of power value is obviously insufficient for normal life support (Table 8). Caloric content and security with proteins are superfluous in the top groups. Malnutrition in the first groups is followed by an overeating in the last that leads to deterioration in indicators of food security on obesity.

Table 6. The actual and rational consumption of the main food in Russia in 2000-2014, kg a year on the person.

\begin{tabular}{|l|c|c|c|c|c|c|}
\hline \multirow{2}{*}{ Food product } & \multirow{2}{*}{$\begin{array}{c}\text { Rational } \\
\text { norm }\end{array}$} & \multicolumn{4}{|c|}{ Actual consumption } & \begin{tabular}{c}
2014 in \% \\
\cline { 3 - 7 }
\end{tabular} \\
\cline { 3 - 7 } & 100 & 117 & 121 & 120 & 118 & 118.0 \\
\hline Grain products & 98 & 109 & 109 & 104 & 111 & 113.3 \\
\hline Potatoes ational \\
\hline $\begin{array}{l}\text { Vegetables and } \\
\text { melon cultures }\end{array}$ & 130 & 79 & 87 & 101 & 111 & 85.4 \\
\hline Fruit, berries & 95 & 32 & 46 & 58 & 64 & 67.4 \\
\hline $\begin{array}{l}\text { Meat and meat } \\
\text { products }\end{array}$ & 73 & 45 & 55 & 69 & 74 & 101.4 \\
\hline $\begin{array}{l}\text { Milk and dairy } \\
\text { products }\end{array}$ & 330 & 215 & 234 & 247 & 244 & 73.9 \\
\hline Eggs (piece) & 260 & 229 & 250 & 269 & 269 & 103.5 \\
\hline Fish and fish & 20 & 14 & 17 & 21 & 23 & 115.0 \\
\hline
\end{tabular}




\begin{tabular}{|l|l|l|l|l|l|l|}
\hline products & & & & & & \\
\hline Sugar & 26 & 35 & 38 & 39 & 40 & 153.8 \\
\hline Vegetable oil & 11 & 10 & 12 & 13 & 14 & 127.3 \\
\hline
\end{tabular}

Table 7. The nutrition and power value of food of households in Russia, on average per day on one member of a household.

\begin{tabular}{|l|c|c|c|c|c|}
\hline \multicolumn{1}{|c|}{ Indicator } & Standard & 2000 & 2005 & 2010 & 2014 \\
\hline $\begin{array}{l}\text { Nutrition value, gram a } \\
\text { day: } \\
\text { proteins }\end{array}$ & & & & & \\
\hline fat & 82 & 62 & 71 & 77 & 78 \\
\hline carbohydrate & 417 & 82 & 96 & 105 & 105 \\
\hline Power value, kcal a day & 2850 & 2394 & 2630 & 2652 & 2603 \\
\hline
\end{tabular}

Table 8. The characteristic of a daily food allowance on decile groups of the population of Russia in 2014 (on average on one member of a household).

\begin{tabular}{|l|c|c|c|c|c|c|c|}
\hline \multirow{2}{*}{ Indicator } & \multirow{2}{*}{ Standard } & \multicolumn{7}{c|}{ Decile groups } \\
\cline { 3 - 8 } & & $\mathrm{I}$ & $\mathrm{III}$ & $\mathrm{V}$ & VII & VIII & $\mathrm{X}$ \\
\hline $\begin{array}{l}\text { Nutrition value, gram a } \\
\text { day: } \\
\text { proteins }\end{array}$ & 82 & 55 & & & & & \\
\hline fat & 95 & 73 & 94 & 78 & 82 & 85 & 94 \\
\hline carbohydrate & 417 & 258 & 307 & 335 & 344 & 354 & 385 \\
\hline Power value, kcal a day & 2850 & 1917 & 2360 & 2613 & 2730 & 2818 & 3080 \\
\hline
\end{tabular}

Table 9. A share of households' expenses on acquisition of food on decile groups in Russia in 2002$2014(\%)$.

\begin{tabular}{|c|c|c|c|c|}
\hline Decile groups & 2002 & 2005 & 2010 & 2014 \\
\hline $\begin{array}{c}\text { I (with the smallest located } \\
\text { resources) }\end{array}$ & 59.0 & 53.0 & 46.2 & 44.9 \\
\hline II & 56.9 & 51.0 & 43.6 & 42.5 \\
\hline III & 55.3 & 48.9 & 41.8 & 40.6 \\
\hline IV & 53.9 & 45.8 & 40.0 & 38.6 \\
\hline V & 51.5 & 42.7 & 39.1 & 37.1 \\
\hline VI & 48.5 & 39.2 & 35.8 & 35.5 \\
\hline VII & 43.7 & 34.6 & 31.3 & 31.6 \\
\hline VIII & 40.3 & 32.4 & 27.6 & 28.6 \\
\hline IX & 37.4 & 28.2 & 25.4 & 24.9 \\
\hline $\begin{array}{c}\text { X (with the greatest located } \\
\text { resources) }\end{array}$ & 29.2 & 21.0 & 18.4 & 15.8 \\
\hline On average on all groups & 41.7 & 33.2 & 29.6 & 28.5 \\
\hline
\end{tabular}

The share of expenses of the population on acquisition of food is one of characteristics of economic availability of the food. The analysis of this indicator in a section of decile groups on the level of the average per capita income in 2002-2014 has shown that the share of expenses on acquisition of food is inversely proportional to the volume of the located resources (Table 9). At the same time, it should be noted a tendency to reduction of a share of expenses on food in all groups of households from $41.7 \%$ to $28.5 \%$. Against growth of nutrition and power value of the consumed food it demonstrates increase in economic availability of the food to all segments of the population.

Strengthening of differentiation of various population groups' income demonstrates existence of threats in system of economic availability of the food. As shows international experience: society enters an instability zone if the ratio in the income of $10 \%$ most and $10 \%$ of the least provided exceeds 8 times $[3,4,6,13]$. In 2014 in Russia this indicator has 
been recorded at the level of 7.3, however the negative tendency of his growth is traced (Table 10).

Table 10. Indicators of economic availability of the food in Russia in 2000-2014.

\begin{tabular}{|l|c|c|c|c|}
\hline \multicolumn{1}{|c|}{ Indicator } & 2000 & 2005 & 2010 & 2014 \\
\hline Ratio of the income X and I decile groups & 6.6 & 6.8 & 7.4 & 7.3 \\
\hline Size of a living wage, rub. & 1210.4 & 3017.5 & 5688.0 & 8050.0 \\
\hline $\begin{array}{l}\text { Average per capita monetary income (in a } \\
\text { month), rub. }\end{array}$ & 2288.0 & 8112.0 & 18958.0 & 27766.0 \\
\hline $\begin{array}{l}\text { Ratio of the average per capita monetary } \\
\text { income of the population with the size of a } \\
\text { living wage, \% }\end{array}$ & 189.0 & 268.8 & 333.3 & 344.9 \\
\hline $\begin{array}{l}\text { The population share with the monetary } \\
\text { income is lower than the size of a living } \\
\text { wage, \% }\end{array}$ & 29.0 & 17.7 & 12.5 & 11.2 \\
\hline
\end{tabular}

\section{Results}

The living wage is one of the key indicators allowing to give an objective assessment of level of economic availability of the food in Russia. Its size is defined on the basis of a consumer basket and data of Federal State Statistics Service on the level of consumer prices of food and essentials. The share of the population which monetary income is lower than the size of a living wage was reduced from $29.0 \%$ in 2000 to $11.2 \%$ in 2014 . Despite positive dynamics of this indicator, the considerable part of the population is below the poverty line and has no opportunity to get the food corresponding on quality and the range to physiological norms.

The ratio of the average per capita income with the size of a living wage is the indicator of growth of population welfare and a possibility of acquisition of qualitative products. In 2000-2014 this indicator annually increased, and as of 2014 it has made $344.9 \%$. It once again demonstrates growth of economic availability of the food in Russia.

\section{Discussion}

Investigating evolution of approaches to definition of food security, it should be noted that the list of the indicators characterizing her significantly has increased [2]. If in the Universal declaration on elimination of hunger and malnutrition of 1974 it is told about food security as about a guarantee of ensuring access of all inhabitants to the food in the quantity necessary for active and healthy life at any time, then the Rome Declaration of 1996 allocates five key principles of steady food security, namely:

1. Physical availability of safe and nutritious food sufficient in a quantitative sense;

2. Economic availability to the food of due volume and quality of all social groups of the population;

3. Stability of national food system;

4. Autonomy and economic independence of national food system;

5. Reliability of national food system concerning minimization of influence of seasonal, weather and other fluctuations on provisioning of the population of all regions of the country $[3,4]$.

At the present stage the basis of food security's formation of the majority of the countries was formed by the regulations FAO's Concept of Food Security (the organizations for agriculture and the food at the UN). Four broad dimensions of food security are usually identified: 
- the food security doesn't mean self-sufficiency by the food\$

- the country has to seek for production of enough products for the needs if there are comparative advantages;

- the country has to be able to import necessary quantity of the food and to provide needs for the food for the citizens;

- the governments have to provide physical and economic availability of the safe food [5].

Using mathematical tools, experts of FAO give an assessment to food security on a number of indicators in a section of four directions: availability, access, utilization, stability. The system of monitoring of food security in Russia is built by similar criteria. At the same time, it should be noted that the offered techniques of an assessment have a number of shortcomings. The majority of shortcomings belongs to lack of objective determination of level of food security at the global, regional or national levels $[4,5,6]$.

\section{Conclusions}

1. The food security is one of the most important directions of ensuring national security of the state. Instability of a foreign policy situation and deepening of financial crisis actualize need of monitoring of food security's condition of as objective condition of economic sovereignty of Russia;

2. The existing approach to an assessment of food security fixed within the Doctrine of food security of the Russian Federation demands serious adjustment regarding development of a method of separate indicators' calculation and their criteria values, specification of information base for carrying out the analysis;

3. The analysis of food independence's condition taking into account volumes of export and import of resources has shown that threshold values are exceeded only on milk and dairy products that is caused by system problems in the field of dairy animal husbandry;

4. Physical availability of the food is reached on seven main groups of food products. Consumption less rational norm is noted on milk and dairy products, vegetables and fruit. The power and nutrition value of a diet isn't balanced that is shown in excess consumption of fats against insufficient inclusion in a diet of proteins and carbohydrates;

5. Economic availability of the food in Russia tends to growth that is confirmed by reduction of a share of expenses on the food in all categories of households accompanied with growth of nutrition and power value of a food allowance; increase in a ratio of the average per capita income with the size of a living wage; reduction of a share of the population which is below the poverty line.

\section{References}

1. Decree of the Russian President №120 (2010)

2. S. Silvia, S. Gomez, Y. Paloma, S. Mary, Bio-based and Applied Economics 1(1), 66 (2012)

3. I. Ushachev, A. Altukhov, L. Bondarenko, V. Tarasov, A. Kostyaev, S. Sukhov, AllRussian research institute of rural economics, 176 (2008)

4. Agro-industrial complex: economy, management 2, 3-6 (1997)

5. B. Clinton, D. Campbell, D. Barker, Sustainability 3, 14-25 (2011)

6. L. Revenko, International processes 13, 10 (2015)

7. http://foodsecurityindex.eiu.com/

8. I. Romanenko, Calls and answers, 166 (2016) 
9. S. Ryabova, A. Teryoshkina, Regional development 3, 76 (2015)

10. N. Shagayda, V. Uzun, Economy questions 5, 71-72 (2015)

11. A. Aganbegyan, Calls and answers, 39 (2015)

12. T. Glukhova, Calls and answers, 303 (2015)

13. A. Mottaeva, MATEC 73, 07020 (2016)

14. A.B. Mottaeva, A. Zheltenkov, I. Stukanova, S. Ryabichenko, S. Zhuk, MATEC 73, 07026 (2016)

15. An.B. Mottaeva, As.B. Mottaeva, Int.Journal of Applied Engineering Research, 10- 23 (2015)

16. An.B. Mottaeva, As.B. Mottaeva, Int. Journal of Applied Engineering Research, 11- 9 (2016)

17. E. Stein, N. Taskaeva, E. Chibisova, Procedia Engineering 165, 1410-1416 (2016)

18. L.V. Nikolova, D.G. Rodionov, A.B. Mottaeva, Int. Journal of Economics and Financial Issues 6(S3), 1-7 (2016) 